\title{
DOXYCYCLINE INTAKE AND DISTRIBUTION IN THE BODY OF BROILER CHICKENS WITH ORNITHOBACTERIOSIS
}

A. M. TYSHKIVSKA, Graduate Student, Department of Pharmacology,

Parasitology and Tropical Veterinary Medicine

http://orcid.org/0000-0003-4419-2174

National University of Life and Environmental Sciences of Ukraine, Kyiv, Ukraine

E-mail: annatyshkivska@gmail.com

V. B. DUKHNYTSKYI, Doctor of Veterinary Sciences, Professor,

Department of Pharmacology, Parasitology and Tropical Veterinary Medicine

http://orcid.org/0000-0002-9670-1244

E-mail: dukhnytskyjvb@ukr.net

National University of Life and Environmental Sciences of Ukraine, Kyiv, Ukraine

M. YU. TYSHKIVSKYI, Candidate of Veterinary Sciences, Associate Professor,

http://orcid.org/0000-0003-0826-5276

E-mail: tyshkivsky@ukr.net

Bila Tserkva National Agrarian University, Bila Tserkva, Ukraine

N. V. TYSHKIVSKA, Candidate of Veterinary Sciences, Associate Professor

http://orcid.org/0000-0003-4937-1390

E-mail: natalya.tyshkivska@gmail.com

Bila Tserkva National Agrarian University, Bila Tserkva, Ukraine

\begin{abstract}
The clinical efficiency of the antibiotic is determined by its distribution in organs and tissues, the ability to penetrate the physiological and pathological barriers of the body. The article presents the results from a study of the intake, distribution, and excretion of doxycycline hyclate - the active substance of the antibiotic pollodoxin from the body of broiler chickens (the Cobb-500 cross) with ornithobacteriosis.

It has been established that 24 hours after the pollodoxin solution application in broiler chickens with ornithobacteriosis, the highest content of its active substance (doxycycline hyclate) was found in the lungs, liver, slightly less - in the kidneys, and least - in the heart and pectoral muscles. After 48 and 72 hours, the content of doxycycline hyclate increases in the liver, kidneys, heart, and pectoral muscles compared to 24 hours, while in the lungs decreases slightly after 48 hours and does not differ from it after 72 hours. At 96 hours, the content of doxycycline hyclate in the kidneys, lungs, and pectoral muscles reaches maximum values; in the liver it is smaller than the previous one (72 hours), while in the heart it does not differ from it. Doxycycline hyclate does not show cumulative properties and "organ affiliation" during 96 hours of entry into the body of broiler chickens with ornithobacteriosis. After 24 hours of discontinuation of pollodoxin use (120 hours of the experiment), the content of doxycycline hyclate
\end{abstract}


in all studied organs decreases but remains high enough, indicating a relatively long elimination half-life and antimicrobial action. Pharmacokinetic indicators will allow the doctor to determine an effective drug that will provide a therapeutic effect and will prevent the development of resistance of microorganisms.

Keywords: pollodoxin, doxycycline hyclate, broiler chickens, ornithobacteriosis, Ornithobacterium rhinotracheale, pharmacokinetic parameters

\section{Introduction}

In conditions of intensive poultry farming, bacterial diseases with predominant respiratory system injury cause great economic damage. In recent years, in poultry farms, previously little-known diseases of various bird species have become widespread in Ukraine. Among them, ornithobacteriosis occupies an important place. The disease is characterized by respiratory system lesions, decreased growth, and increased mortality rates.

Considering that ornithobacteriosis causative agent (Ornithobacterium rhinotracheale) affects, foremost, the respiratory organs - lungs, trachea, air sacs, and the disease is often complicated by other microorganisms (mycoplasmas), or a secondary disease, therefore, pluripotential antibiotics are preferred in the treatment.

One of the main indicators that determine the antibiotic effectiveness in the body is its high bioavailability, the ability to penetrate and accumulate in high concentrations in the places of the pathological process, to have an elimination half-life sufficient for the antimicrobial effects (Fairchild et al., 2005; Sanders et al., 2016).

Several factors, among which the most important are the drug's chemical structure, the administration route, the frequency and duration of use, the animal's age, and the pathology presence
(Ambrose et al., 2007; Barbosa et al., 2020), affect the drugs' bioavailability and distribution in the body.

Therefore, it is currently topical to study individual pharmacokinetic parameters of chemotherapeutic agents in the body of broiler chickens with ornithobacteriosis in order to find the most effective one.

\section{Analysis of recent researches and publications}

Ornithobacteriosis is a respiratory system disease in poultry, which is widespread in the world and causes significant economic damage. In broiler chickens, ornithobacteriosis leads to stunting and significant growth retardation, air sacculitis, pneumonia, and death. The disease develops as an independent nosological unit. It can also complicate the course of other bacterial and viral diseases (Ellakany et al., 2019).

Viruses cause integrity disruption of the respiratory system's mucous membrane, and so open the way for bacteria. The main pathogens of the respiratory system's pathology are $O$. rhinotracheale and mycoplasma. The ornithobacteriosis causative agent widespread occurrence is evidenced by the monitoring results of industrial poultry in Germany. During this monitoring, it was found that about $90 \%$ of the investigated birds had antibodies to the ornithobacteriosis causative agent (Szabó et al., 2017). 
The ornithobacteriosis causative agent $(O$. rhinotracheale) is a small, gram-negative bacillus with rounded ends, does not form spores and capsules. It is extremely difficult to isolate it by classical bacteriological methods, and therefore, ornithobacteriosis often remains an "undiagnosed" and "undertreated" infection.

The circulating strains' wide population (449 strains and 9 serovars), the rapid development of resistance, and the $O$. rhinotracheale ability to acquire cross-species resistance due to plasmid conjugation significantly complicates the treatment of birds with ornithobacteriosis (Oca-Jimenez et al., 2017).

In vitro, several antibiotics are effective against $O$. rhinotracheale but, in practice, the results are ambiguous. The reason for this is precisely that the ornithobacteriosis causative agent is "accompanied" by other pathogens and a large number of $O$. rhinotracheale serotypes, the sensitivity of which to chemotherapeutic agents is rapidly changing.

$O$. rhinotracheale are most sensitive to tetracyclines, macrolides, fluorfenicol, semi-synthetic penicillins. In the European countries and Ukraine, it is recommended to control ornithobacteriosis by using antibiotics of the tetracycline and macrolide group (Mayahi et al., 2016).

Tetracyclines belong to broad-spectrum antibiotics and have high biological activity. Tetracycline's positive characteristics are resistance to digestive enzymes and gastric juice, the ability to be rapidly absorbed from the digestive tract, which is important for oral administration (Smith \& Leyden, 2005; Ochsendorf, 2010; Bailey et al., 2016).

The pharmacokinetics of tetracyclines begins with the substance absorption in the initial part of the small bowel, and the effective concentration in the blood is reached in 2-4 hours. However, oral bioavailability varies significantly between drugs. In particular, doxycycline is better absorbed after internal administration, while chlortetracycline is almost not absorbed (Agwuh \& MacGowan, 2005).

One of the most common tetracycline antibiotics used in veterinary medicine is doxycycline. It is a semi-synthetic antibiotic with a bacteriostatic effect. It has a wide spectrum of action against gram-negative and gram-positive aerobic and anaerobic bacteria, rickettsia, chlamydia, mycoplasma, and some protozoa (Roberts \& Chopra, 2001; Mileva \& Milanova, 2020).

Compared to other tetracyclines, the doxycycline's pharmacokinetic properties include better lipid solubility and tissue distribution, complete absorption, and a long half-life (Ho et al., 2014; Papich et al., 2016). The doxycycline's antimicrobial activity in vitro is more effective than in other tetracyclines, therefore, its best activity for the treatment of patients with respiratory pathology is noted (Bousquet et al., 1997; Widyasari-Mehta et al., 2016).

The drug's distribution and accumulation in the organs are important indicators that determine the antibiotic's activity at the site of the pathogen. The study of the doxycycline accumulation in the broiler chickens' organs shows that with the doxycycline introduction at a dose of $20 \mathrm{mg} / \mathrm{kg}$ b.w., on the 5 th day of use the antibiotic in the highest concentration was found in the kidneys and liver, then in the lungs, and the lowest in the muscles (Anadón, et al., 1994). In other studies, 5 days after feeding 35-day-old broiler chickens with doxycycline at a dose of $10 \mathrm{mg} / \mathrm{kg}$ b.w., the highest drug concentrations were found in the kidneys, which was $6.5 \mu \mathrm{g} / \mathrm{g}$, in the liver $4.79 \mu \mathrm{g} / \mathrm{g}$, in the muscles $-1.46 \mu \mathrm{g} / \mathrm{g}$, in 
the skin $-1.23 \mu \mathrm{g} / \mathrm{g}$. The drug was completely excreted from the muscles after 6 days, from the liver and kidneys -8 , from the skin -7 days (Mestorino et al., 2018). Similar results were also obtained by other researchers, finding the highest drug concentrations in the kidneys and liver (Kramer et al., 1978; Croubels et al., 1998; Gajda et al., 2014).

Purpose - to investigate the distribution of doxycycline hyclate when it is used in the form of the drug pollodoxin in the body of broiler chickens with ornithobacteriosis.

\section{Materials and methods of research}

All stages of research were carried out in accordance with the "European Convention for the Protection of Vertebrate Animals used for Research and Other Scientific Purposes" (Strasbourg, 1986) and approved by the Commission on Bioethics. The laboratory analysis was carried out in 2019-2020 on the basis of the chemical analytical sector of the Expert Center for Diagnostics and Laboratory Support "Biolights" (urban-type settlement Baryshivka), accredited in accordance with the requirements of DSTU ISO/IEC 17025:2017 according to № 201864, and on the basis of the laboratory of the pharmacology of the Department of Pharmacology, Parasitology and Tropical Veterinary Medicine, the National University of Life and Environmental Sciences of Ukraine (Kyiv). Statistic for analysis of experimental data was carried out by conventional methods of variation statistics and using the computer program Microsoft Excel 2019. The research was carried out on the basis of a poultry farm in Ivano-Frankivsk region. For the research, 20 broiler chickens of the Cobb500 cross at the age of 25 days, with an av- erage body weight of $1200 \mathrm{~g}$, were used. By means of bacteriological examination, ornithobacteriosis was diagnosed in broiler chickens, which in some of them was complicated by colibacillosis.

Bacteriological research. To identify the causative agents of pneumonia and aerosaculitis, from a bird slaughtered in a state of light ether anesthesia, swabs were taken from the tracheal mucosa using a sterile SWAB applicator of the Biomerieux trademark. Selected material from the tracheal mucosa was plated by direct inoculation on blood agar. The cultivation was carried out under microaerophilic conditions at $37^{\circ} \mathrm{C}$ for 48 hours. The growth of small matte gray colonies was found after cultivation.

Maldi-Tof Mass Spectrometry. The two-day culture was identified by the method of Maldi-Tof mass spectrometry by direct deposition. The basic solvent was prepared from $475 \mu \mathrm{l}$ of ultrapure deionized water, $500 \mu \mathrm{l}$ of acetonitrile and $25 \mu \mathrm{l}$ of $100 \%$ trifluoroacetic acid. To prepare the matrix, $250 \mu$ of stock solution was added to a test tube with $\alpha$-cyano-4-hydroxy-brown acid (HCCA). The mixture was vortexed thoroughly for $5 \mathrm{~min}$ until completely dissolved. To control the compliance and intensity of the peaks, the instrument was calibrated with the $100 \%$ concentration Bruker bacterial test standard (cat. № 255343). A small amount of bacterial culture was applied in a thin layer to the surface of the target strip. After drying, the dot was covered with $1 \mu \mathrm{l}$ of the HCCA matrix solution, and an hour after its complete drying, the detection was performed. Mass spectra were obtained using Maldi-Tof in the mass range of m/z from 3000 to 20,000. The SCiLS Lab software was used to collect spectra, identify peaks, and analyze them. All settings and manufactur- 
er's recommendations for standard use were employed.

For research, we used the drug pollodoxin of the INVESA trademark (the active substance is doxycycline hyclate $100 \mathrm{mg} / \mathrm{ml}$ ), which was mixed in an amount of $1 \mathrm{~cm}^{3}$ with $1000 \mathrm{~cm}^{3}$ of drinking water. The broiler chickens were watered with pollodoxin solution for 4 days instead of drinking water in accordance with the recommended scheme used in industrial poultry farming. For poultry feeding, we used full-feed compound feeds produced by "Plakhtyanskiy Kormy".

The doxycycline hyclate intake and distribution in the body of broiler chickens with ornithobacteriosis was determined 24, 48, 72, and 96 hours after the pollodoxin solution administration per os. To determine the doxycycline hyclate content in the internal organs, three chickens were slaughtered in a state of light ether anesthesia in 120 hours from the beginning of the experiment. Pathological material samples (pectoral muscles, heart, lungs, liver, and kidneys) were frozen. Doxycycline hyclate determination by liquid chromatography-mass spectrometry was performed after preliminary extraction with acetonitrile and subsequent purification of the samples. Extraction, concentration, and purification of the studied samples were carried out on columns for solid-phase extraction. Doxycycline hyclate was extracted from the column with the eluent. The identification was performed by the time of the content, and the quantitative determination was carried out by the external standards method, by the area of the peaks. A Waters LC/MS/MS liquid chromatograph with a Premier XE tandem quadrupole detector was used for detection. The research results were considered by the variation statistics methods.

\section{Results of the research and their discussion}

During the clinical examination of sick broiler chickens, a general depression, ruffled plumage, apathy, and refusal to feed were noted. In some individuals, nasal discharge and swelling of the nasal mucosa were observed.

Bacteriological studies with the identification of Maldi-Tof mass spectrometry identified the isolated culture of microorganisms from the trachea as O. rhinotracheale (Fig. 1). The research results shown in Fig. 1 are original protocols that are automatically generated by the SCiLS Lab software.

After 24 hours from the beginning of the administration of the pollodoxin solution, its active substance (doxycycline hyclate) was distributed in descending order in the organs: lungs $>$ liver $>$ kidneys $>$ heart $>$ pectoral muscles (Table 1).

The distribution of doxycycline hyclate depended on the structure of the studied organs. Data in Table 1 show that after 24 hours, its content in the parenchymal organs (kidneys, liver, lungs) was 1.6-2.4 times higher than in the muscles and heart, the basis of the structure of which are striated muscles.

In 48 hours after the start of drinking the pollodoxin solution, the content of doxycycline hyclate increased compared to the previous value in the liver by $21 \%$, kidneys - by $35 \%$, heart - by $15 \%$, pectoral muscles - by $10 \%$. The content of doxycycline hyclate in the lungs during this experimental period decreased compared to the previous figure by $4 \%$.

Drinking a pollodoxin solution during the third day was accompanied by a further increase in the content of doxycycline hyclate in the studied organs. Thus, at 72 hours, its content in the liver, kidneys, heart, and muscles was higher 
Analyte 3

Analyte Name:

3

Analyte Description:

s.o

Analyte ID:

2223-1

Analyte Creation Date Time:

2019-12-17T10:19:44.555

Applied MSP Library(ies):

Applied Taxonomy Tree:

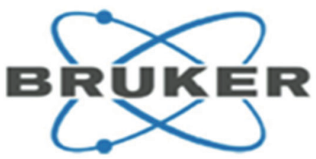

\begin{tabular}{|c|c|c|c|}
\hline $\begin{array}{c}\text { Rank } \\
\text { (Quality) }\end{array}$ & Matched Pattern & $\begin{array}{c}\text { Score } \\
\text { Value }\end{array}$ & $\begin{array}{c}\text { NCBI } \\
\text { Identifier }\end{array}$ \\
\hline $\begin{array}{c}1 \\
(++)\end{array}$ & Omithobacterium rhinotracheale GD60 GDD & 2.419 & $\underline{28251}$ \\
\hline $\begin{array}{c}2 \\
(++)\end{array}$ & Omithobacterium rhinotracheale 11_00488_01 VAXM & 2.291 & $\underline{28251}$ \\
\hline $\begin{array}{c}3 \\
(+)\end{array}$ & Omithobacterium rhinotracheale 11_00507_01 VAXM & 1.998 & $\underline{28251}$ \\
\hline $\begin{array}{c}4 \\
(+)\end{array}$ & Omithobacterium rhinotracheale DSM 15997T DSM & 1.894 & $\underline{28251}$ \\
\hline
\end{tabular}

Fig. 1. Identification protocol of the studied cultures by mass spectrometry obtained using the SCiLS Lab software

by $24 \%, 44,23$, and $21 \%$, respectively, than at 24 hours. The content of doxycycline hyclate in the lungs did not differ from that determined at 24 hours.

After 96 hours, the content of doxycycline hyclate in the kidneys, lungs, and muscles was higher in all previous study periods while in the liver it decreased to the level determined at 24 hours.

Data in Table 1 show that doxycycline hyclate in the body of broiler chickens with ornithobacteriosis is distributed in the largest quantities in the liver, kidneys, and lungs, and in much smaller - in the heart and muscles. Studies have not established an organ, in which doxycycline hyclate accumulates to maximum values in all periods of research, which indicates the absence of "organ affiliation" and material accumulation.

Higher levels of doxycycline hyclate in the liver, kidneys, and lungs than in the heart and muscles are explained by the better blood supply to these organs, as well as their participation in the processes of biotransformation and excretion from the body. Similar results on the distribution of doxycycline in broiler chickens have been obtained by foreign researchers, like us, but in studies conducted on healthy chickens.

1. The content of doxycycline hyclate in the organs of broiler chickens with ornithobacteriosis after feeding a solution of pollodoxin, $\mu \mathrm{g} / \mathrm{g}(\mathbf{M} \pm \mathbf{m}, \mathbf{n}=\mathbf{3})$

\begin{tabular}{|l|c|c|c|c|c|}
\hline \multirow{2}{*}{ Organ } & \multicolumn{5}{|c|}{ Research time, hours } \\
\cline { 2 - 6 } & 24 & 48 & 72 & 96 & 120 \\
\hline Muscle & $2.11 \pm 0.06$ & $2.32 \pm 0.11$ & $2.56 \pm 0.31$ & $3.12 \pm 0.04$ & $1.09 \pm 0.02$ \\
\hline Kidney & $4.27 \pm 0.19$ & $5.80 \pm 0.08$ & $6.15 \pm 0.03$ & $6.19 \pm 0.02$ & $2.49 \pm 0.28$ \\
\hline Liver & $5.02 \pm 0.05$ & $6.09 \pm 0.06$ & $6.24 \pm 0.08$ & $5.04 \pm 0.45$ & $2.07 \pm 0.03$ \\
\hline Lung & $5.09 \pm 0.08$ & $4.90 \pm 0.10$ & $5.06 \pm 0.12$ & $5.62 \pm 0.23$ & $1.61 \pm 0.23$ \\
\hline Heart & $2.68 \pm 0.44$ & $3.09 \pm 0.04$ & $3.30 \pm 0.20$ & $3.28 \pm 0.10$ & $1.39 \pm 0.21$ \\
\hline
\end{tabular}


After discontinuation of feeding a pollodoxin solution, the content of doxycycline hyclate in the internal organs decreases intensively, which indicates its biotransformation and excretion from the body (Table 1). Thus, 24 hours after discontinuation of pollodoxin (120 hours of the experiment) the content of doxycycline hyclate was lower than 96 hours: in the lungs -3.4 times, pectoral muscles 2.9 times, kidneys -2.5 times, liver and heart - 2.4 times (Kramer et al., 1978; Anadón, et al., 1994; Croubels et al., 1998; Gajda et al., 2014; Widyasari-Mehta et al., 2016; Mestorino et al., 2018; Tyshkivska et al., 2020).

Although the content of the active substance (doxycycline hyclate) in the studied organs decreased rapidly $24 \mathrm{~h}$ after discontinuation of the pollodoxin solution, its relatively high levels indicate a long elimination half-life and antimicrobial action.

\section{Conclusions and future perspectives}

When feeding with pollodoxin solution broiler chickens with ornithobacteriosis, in accordance with the recommended scheme, the highest concentrations of its active substance (doxycycline hyclate) were found in the liver, kidneys, and lungs. Research has not established the cumulative properties and "organ affiliation" to doxycycline hyclate.

A day after the pollodoxin discontinuation in broiler chickens with ornithobacteriosis, doxycycline hyclate was distributed in the following sequence: pectoral $\quad$ muscles $<$ heart $<$ lungs $<$ liv$\mathrm{er}<$ kidneys. Directions for future research are to study the pharmacokinetic characteristics of antibiotics of other groups in the body of broiler chickens with ornithobacteriosis.

\section{References}

Agwuh, K. N., \& MacGowan, A. (2006). Pharmacokinetics and pharmacodynamics of the tetracyclines including glycylcyclines. Journal of Antimicrobial Chemotherapy, 58, 256-265. doi: 10.1093/jac/dkl224

Ambrose, P. G., Bhavnani, S. M., Rubino, C. M., Louie, A., Gumbo, T., Forrest, A., \& Drusano, G. L. (2007). Pharmacokinetics-pharmacodynamics of antimicrobial therapy: it's not just for mice anymore. Clinical Infection Diseases Journal, 44, 79-86. doi: 10.1086/510079

Anadón, A., Martinez-Larrañaga, M. R., Diaz, M., Bringas, J. P., Fernandez, M. C., Fernandez-Cruz, M. L., Iturbe, J., \& Martinez, M. A. (1994). Pharmacokinetics of doxycycline in broiler chickens. Avian Pathology, 23(1), 7990. doi: 10.1080/03079459408418976

Bailey, C., Spielmeyer, A., \& Hamscher, G. (2016). The veterinary antibiotic journey: comparing the behaviour of sulfadiazine, sulfamethazine, sulfamethoxazole and tetracycline in cow excrement and two soils. Journal of Soils and Sediments, 16, 16901704. doi: 10.1007/s11368-016-1370-0

Bousquet, E., Morvan, H., \& Aitken, I. (1997). Comparative in vitro activity of doxycycline and oxytetracycline against porcine respiratory pathogens. The Veterinary record, 141(2), 37-40. doi: 10.1136/vr.141.2.37

Barbosa, E. V., Cardoso, C. V., Silva, R., Cerqueira, A., Liberal, M., \& Castro, H. (2020). Ornithobacterium rhinotracheale: an update review about an emerging poultry pathogen. Veterinary Science, 7(1), 1-13. doi: 10.3390/vetsci7010003

Cazer, C. L., Volkova, V. V., \& Gröhn, Y. T. (2014). Use of pharmacokinetic modeling to assess antimicrobial pressure on enteric bacteria of beef cattle fed chlortetracycline for growth promotion, disease control, or treatment. Foodborne pathogens and disease, 11(5), 403-411. doi: 10.1089/ fpd.2013.1677 
Croubels, S., Baert, K., \& Busser, P. (1998) Residue study of doxycycline and 4-epidoxycycline in pigs medicated via drinking water. The Analyst, 23(12),2733-2736. doi: 10.1039/a804936j.

Ellakany, H. F., Elbestawy, A. R., Abd-Elhamid, H. S., Gado, A. R., Nassar, A. A., Abdel-Latif, M. A., ... \& Alowaimer, A. (2019). Effect of experimental Ornithobacterium rhinotracheale infection along with live infectious bronchitis vaccination in broiler chickens. Poultry Science, 98(1), 105-111. doi: 10.3382/ps/pey324

Fairchild, A. S., Smith, J. L., Idris, U., Lu, J., Sanchez, S., Purvis, L. B., ... \& Lee, M. D. (2005). Effects of orally administered tetracycline on the intestinal community structure of chickens and on tet determinant carriage by commensal bacteria and Campylobacter Jejuni. Applied and environmental microbiology, 71(10), 5865-5872. doi: 10.1128/ AEM.71.10.5865-5872.2005

Gajda, A., Posyniak, A., \& Tomczyk, G. (2014). LC-MS/MS analysis of doxycycline residues in chicken tissues after oral administration. Bulletin of the Veterinary Institute in Pulawy, 58(4), 573-579. doi: 10.2478/bvip-2014-0089

Ho, Y. B., Zakaria, M., Latif, P. A., \& Saari, N. (2014). Occurrence of veterinary antibiotics and progesterone in broiler manure and agricultural soil in Malaysia. The Science of the total environment, 488, 261-267.

Kramer, P. A., Chapron, D. J., Benson, J., \& Mercik, S. A. (1978). Tetracycline absorption in elderly patients with achlorhydria. Clinical Pharmacology and Therapeutics, 23(4), 467-472. doi: 10.1002/cpt1978234467

Mayahi, M., Gharibi, D., \& Ghadimipour, R. (2016). Isolation, identification and antimicrobial sensitivity of Ornithobacterium rhinotracheale in broilers chicken flocks of Khuzestan, Iran. Veterinary Research Forum, 7(4), 341-346.

Mestorino,O.N.,Zeinsteger,P.A.,Buchamer,A.V., Buldain, D. C., Aliverti, F., \& Marchetti, M. L. (2018). Tissue depletion of doxycycline after its oral administration in food pro- ducing chicken for fattening. International Journal of Avian \& Wildlife Biology, 3. doi: 10.15406/ijawb.2018.03.00095

Mileva, R., \& Milanova, A. (2020). Doxycycline pharmacokinetics in mammalian species of veterinary interest - an overview. Bulgarian Journal of Veterinary Medicine. Online first, 3-20. doi: 10.15547/bjvm.2321

Oca-Jimenez, R. M., Vega-Sanchez, V., Morales-Erasto, V., Salgado-Miranda, C., Blackall, P., \& Soriano-Vargas, E. (2018). Phylogenetic relationship of Ornithobacterium rhinotracheale strains. The Journal of veterinary medical science, 80(6), 869-873. doi: 10.1292/jvms.17-0474

Ochsendorf, F. Minocycline in acne vulgaris: benefits and risks. American journal of clinical dermatology, 11, 327-341. doi: 10.2165/11319280-000000000-00000

Papich, M. G., Fortier, L. A., \& Davidson, G. S. (2013). Doxycycline concentration over time after storage in a compounded veterinary preparation. Journal of the American Veterinary Medical Association, 12, 1674 1678. doi: 10.2460/javma.242.12.1674

Roberts, M., \& Chopra, I. (2001). Tetracycline antibiotics: mode of action, applications, molecular biology, and epidemiology of bacterial resistance. Microbiology and molecular biology reviews, 65, 232-260. doi: 10.1128/MMBR.65.2.232-260.2001

Sanders, P., Henri, J., Laurentie, M., \& Sanders, P. (2016). Tools to evaluate pharmacokinetics data for establishing maximum residue limits for approved veterinary drugs: examples from JECFA's work. Drug testing and analysis, 8, 565-571. doi: 10.1002/dta.2006.

Smith, K., \& Leyden, J. (2005). Safety of doxycycline and minocycline: a systematic review. Clinical Therapeutics, 27, 1329-1342.

Szabó, R., Wehmann, E., Makrai, L., Nemes, C., Gyuris, É., Thuma, Á., \& Magyar, T. (2017). Characterization of Ornithobacterium rhinotracheale field isolates from Hungary. Avian Pathology, 46(5), 506-514. doi: 10.1080/03079457.2017.1321104 
Tyshkivska, A., Dukhnitsky, V., \& Tyshkivsky, M. (2020). Intake and distribution of doxycycline in the organism of broiler chickens. Scientific Journal of Veterinary Medicine, 2020 (2), 158-165. doi: 10.33245/23104902-2020-160-2-158-165
Widyasari-Mehta, A., Suwito, H. R. K. A., \& Kreuzig, R. (2016). Laboratory testing on the removal of the veterinary antibiotic doxycycline during long-term liquid pig manure and digestate storage. Chemosphere, 149, 154-160. doi: 10.1016/j.chemosphere.2016.01.094

А. М. Тишківська, В. Б. Духницький, М. Я. Тишківський, Н. В. Тишківська (2021). НАДХОДЖЕННЯ ТА РОЗПОДІЛ ДОКСИЦИКЛІНУ В ОРГАНІЗМІ КУРЧАТ-БРОЙЛЕРІВ, ХВОРИХ НА ОРНІТОБАКТЕРІО3. Ukrainian Journal of Veterinary Sciences, 12(1):

5-13, https://doi.org/10.31548/ujvs2021.01.001

Анотація. Клінічна ефекктивність антибіотика визначається його розподілом в органах і тканинах, здатністю проникати через фізіологічні та патологічні барлєри організму. У статті наведено результати досліджень надходження, розподілу та виведення доксицикліну гіклату - діючої речовини антибіотика польодоксину з організму курчат-бройлерів кросу КОББ-500 хворих на орнітобактеріоз.

Встановлено, що через 24 год після застосування польодоксину хворим курчатамбройлерам, найбільше доксицикліну гіклату міститься в легенях і печінці, дещо менше - 8 нирках, а найменше - у серці та грудних м'язах. Через 48 та 72 год вміст доксицикліну гіклату зростає у печінці, нирках, серці та грудних м'язах порівнюючи з показником на 24 год, тоді як у легенях незначно зменшується через 48 год та не відрізняється від нього через 72 год. На 96 год вміст доксицикліну гіклату у нирках, легенях та грудних м'язах набуває максимальних значень; у печінці він менший за попередній (на 72 год), тоді як у серці не відрізняється від нього. Доксицикліну гіклат не проявляє кумулятивних властивостей та «органної приналежності» впродовж 96 год надходження в організм хворих на орнітобактеріоз курчат-бройлерів. Через 24 год після припинення застосування польодоксину (на 120 год досліду), вміст доксицикліну гіклату в усіх досліджуваних органах зменшується, однак залишається достатньо високим, що засвідчує порівняно тривалий період його напіввиведення та протимікробну дію. Показники фармакокінетики дадуть змогу лікарю визначити ефективний препарат, який забезпечить терапевтичний ефект, і буде запобігати розвитку резистентності мікроорганізмів.

Ключові слова: польодоксин, доксицикліну гіклат, курчата-бройлери, орнітобактеріоз, Ornithobacterium rhinotracheale, показники фармакокінетики 